\title{
Analysis of Satisfaction to The User of The Elementery Teacher Study Program Graduates Faculty of Teacher Training and Education, Pakuan University
}

\author{
Elly Sukmanasa $^{*}$, Lina Novita ${ }^{*}$, Fitri Siti Sundari ${ }^{*}$ \\ 1), 2), 3) University of Pakuan, Bogor, Indonesia \\ Corresponding Author: ellysukmanasa@unpak.ac.id
}

\begin{abstract}
This research uses qualitative approach. The problem in this research is that students of PGSD graduates still have to deepen their mastery of English, lack of implementing the use of technology and information tools, and lack of expertise in self-development field. User satisfaction of graduates can be measured from 7 (seven) aspects of the ability of PGSD graduate in the field. The seven aspects are integrity (ethics and morals), professionalism (expertise by field), English, information technology skills, communication, teamwork, and self-development. User satisfaction graduates produce good values in six aspects $(85.7 \%)$, namely aspects of integrity, professionalism, communication, use of information technology, teamwork, and self-development. While as much as one aspect (14.3\%) the results are quite good. This aspect is English proficiency. This indicates that the study program must be really serious in improving the English language skills of PGSD students to be able to learn it better. Good listening, writing, speaking, and grammar skills.
\end{abstract}

Keywords: satisfaction, users, students

\section{INTRODUCTION}

Elementary School Teacher Study Program (hereinafter referred to as PGSD) Faculty of Teacher Training and Education Universitas Pakuan Bogor is a service provider institution in the field of education required by prospective students. The PGSD study program is one of the study programs that are quite popular among the people in Bogor and surrounding areas. Cooperation between Prodi PGSD FKIP Unpak with graduate users of primary school in Bogor and surrounding areas will be established continuously if the graduate users are satisfied with the quality of teachers generated. User satisfaction of this graduate will be a barometer for PGSD FKIP Unpak program in terms of curriculum development, competence, or course that is required by elementary school but not yet represented in the courses contained in PGSD FKIP Unpak. Data on the satisfaction of institutions that use the graduate of Prodi PGSD FKIP Unpak needs to be explored at all times in order to develop the institution in a sustainable manner. This data is very important to Prodi PGSD FKIP Unpak get updated feedback about some indicators for the development of institutions. PGSD FKIP Unpak has produced 912 graduate students who mostly have got the job in accordance with their field of teaching in elementary schools in various regions, especially Bogor city and district. This happens because when conducting the Field
Experience Program (PPL) many PGSD students are recruited by the school where they implement the PPL. Based on the results of a closed interview and the results of questionnaire distribution based on alumni search and graduate users who facilitated the Quality Assurance Guidelines of Study Programs and through the website Unpak.ac.id of some graduate users can be said that students of PGSD graduates still have more experience in the mastery of English, lack of implementing the use of technology and information tools, lack of expertise in the field of self-development.

Users or stakeholders are individuals, groups of people, communities or communities either as a whole or partially with relationships and interests of the institution. Individuals, groups, as well as communities and communities can be said to be stakeholders if they have characteristics, which have the power, legitimacy, and interests of the company or institution. (Budimanta, 2008: 87). Users of graduates or stakeholders are external parties who are consumers for the output of an educational institution. These external parties can be governmental, private, or individual (Setyaningsih and Abrori, 2013: 4). Users of graduates or stakeholders are closely related to the conditioning of educational institutions residing in the college environment, which essentially the purpose of educational institutions is to create and maintain the satisfaction of stakeholders. 
The world of education, as one form of service in society, can also apply the above principles. According to Pandapat of Indahwati, (2008: 172) that the measurement of the extent to which educational institutions are able to meet customer expectations, can be used as a starting point to determine the quality of educational services of an educational institution. This is realized through measuring the level of satisfaction of education service stakeholders. Stakeholders (stakeholders) are associated with several parties namely the interen and the eksteren. Internal parties are the organizational stakeholders that are employees of managers and non managers. External parties consist of: organizational owners and funders of the organization and most of all are customers. Based on the opinion of Tjiptono, (2006: 121) said that until now there has been no agreement on the concept of customer satisfaction, whether satisfaction is an emotional response or cognitive evaluation. Kottler defines customer satisfaction or stakeholders as the feeling of pleasure or disappointment of someone who derives from the comparison between his impression of the performance or the outcome of a product and his expectations Mowen in Tjiptono (2006: 349) says customer satisfaction or stakeholders is the overall attitude towards a good or service after acquisition and use. The satisfaction of graduate users is closely related to the satisfaction of the students during their stay and the activity at a high level so that the satisfaction of the students or the users of the graduates of stakeholders is a comparison between the expectation that the students want when they enroll into certain college students, with what they feel at the moment follow the learning on campus (perception). When viewed from the point of view of college service users, the hope is the desire to get graduates ready to enter their world, whereas perception is what is seen, experienced by the work of college graduates. Various ways of alumni tracking by universities to control and control the quality of higher education, as well as in the PGSD study program, with the formation of Quality Assurance Guidelines of Study Program can facilitate the tracking or tracking of alumni and graduate users other than by meeting directly with alumni or users of stakeholders graduates through seminars or special events on a periodic basis by way of online data filling provided by the university and by the faculty of education and education. Tracer study is a tool to obtain the data needed for the development of quality and quantity of a college. Tracer study is an academic activity that is necessary and must be implemented by universities in order to be able to obtain feedback from graduates and graduate users about the relevance of the educational process that has been undertaken with the ability to improve the living standards of graduates in the community (Anonymous, 2010: 4). Tracer study in this study aims to obtain information from stakeholders or graduate users about the performance of PGSD alumni, after entering the world of work, viewed from the ability aspects: (1) integrity (ethics and morale), (2) expertise based on the field of science (professionalism ), (3) English, (4) use of information technology, (5) communication, (6) teamwork, and (7) selfdevelopment. This information is used to evaluate the performance of graduates in the context of improving the learning system and curriculum in the Primary School Teacher Education Study Program. Feedback (feedback) is aimed specifically at the graduate or school users where the alumni have devoted their knowledge so far. Based on several theories described above can be synthesized that several factors that affect the graduate or stakeholder users are internal factors and external factors that can affect the development of a college. To observe the development of higher education among others by observing from various aspects after entering the world of work, seen from the ability aspects: (1) integrity (ethics and morals), (2) expertise based on the field of science (professionalism), (3) English, 4) use of information technology, (5) communication, (6) teamwork, and (7) self-development.

\section{RESEARCH METHODS}

The research approach used in this research is to use qualitative approach. Qualitative research has characteristics by describing a real situation, but the report is not merely a report of an event without a scientific interpretation (Satori, 2009: 25-26). This study aims to obtain a picture of what it is about how the performance of lecturers on student satisfaction. Data obtained from this research is the result of document analysis, observation, interview, and quesioner where this is in accordance with the opinion of Syaodih (2009). The type of data used in this study is in the form of narrative, description, explanation, and questionnaire filling from both oral and written informants described in the form of field notes, questionnaires, and documentation.

The research flow is as follows:

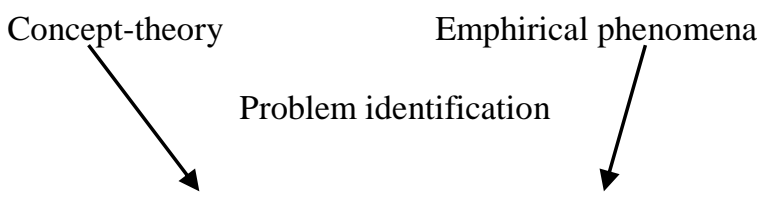

Central theme of the problem

Figure 1 Qualitative Research Flow (Satori, 2009: 37)

The data source of this research is graduate of Teacher Education Program of Elementary School of Teacher Training and Education Faculty of Pakuan University registered as teacher in elementary school. 
Informants specified are informants in accordance with the category of research so that the type used in this study is purposive sampling. Informants in this research are elementary school that use the graduate of Prodi PGSD FKIP Unpak as a teacher.

Data collection techniques are conducted in a wide and deep manner through observation, interview (interview instruments are open, structured with guidelines), documentation study. This is in accordance with the opinion Sugiyono (2009: 225) stating that the data collection can be obtained from the results of observation, interviews, documentation, and combined / triangulation. In this study used data collection techniques by way of observation, questionnaires, interviews, and documentation.

The data analysis technique used is descriptive narrative applied through three paths that is data reduction (making abstraction, that is taking and recording useful information in accordance with research context or ignoring unnecessary words so that the sentence is obtained only, but the language is appropriate with informant language), data presentation, and verification (Satori, 2009: 221). McDrury (Collaborative Group Analysis of Data, 1999) in Moleong (2007: 248) states that the stages of qualitative data analysis are a) reading / studying data, marking key words and ideas in the data, b) studying key words it, trying to find the themes that come from the data, c) Write down the found model, and d) The coding has been done.

Every research must have credibility so it can be accounted for. The credibility of qualitative research is the success of reaching the intention of exploring the multiple problem or the reliability of the results of research data. Efforts to maintain credibility in research are through the following steps (Sugiyono, 2009: 270276): a) Extension of observation, b) Increasing persistence (make more careful and continuous observations, to check whether the data has been found false or not), c) Triangulation (checking data from various sources in various ways, and at various times), d) Negative case analysis (the researcher looks for data that is different or contrary to the findings of previous data If there is no different data or contrary to findings, means the data found to be reliable), e) Using reference materials, and f) Conducting member check (data checking process obtained by the researcher to the data provider If the data found agreed by the data giver means that the data is valid, so the more credible or trusted, but if the data found by researchers with various penafsi The researcher should discuss with the data giver, and if the difference is sharp, the researcher must change the findings, and must adjust to what the data provider provides).

\section{RESULTS AND DISCUSSION}

Data obtained from this research are as follows:

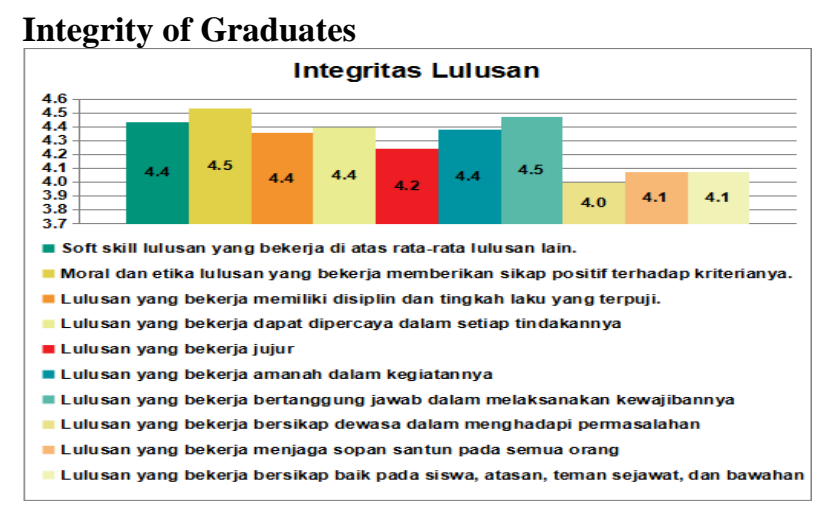

Figure 2. Data of Graduate Integrity Research Results

Information :

$$
1 \text { = not good; } 2 \text { = less good; } 3 \text { = good enough; }
$$$$
4=\text { good; } 5=\text { very good }
$$

Based on the above data, it can be seen that all the integrity indicators of PGSD student graduates give good results. the integrity indicators of graduates consist of soft skills graduates who work above the average of other graduates, the morale and ethics of graduates who work to give a positive attitude to the indicators, graduates who work to have discipline and behavior that is praiseworthy, graduates who work can be trusted in every action, graduates who work honestly, graduates who work mandate in their activities, graduates who work responsibly in carrying out their obligations, mature in the face of problems, maintain good manners to everyone, and be nice to students, superiors, peers, and subordinates. Looking at the data above shows that the learning process in shaping student integrity has been quite successful. This is evident from the good assessment of the stakeholder of Unpak PGSD graduate.

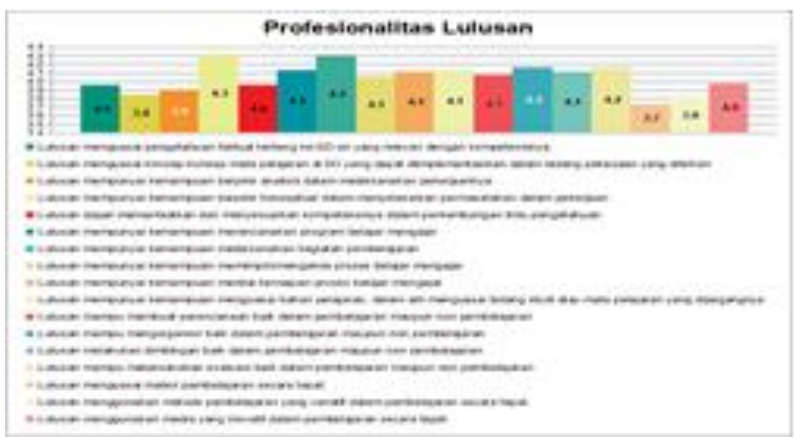

Figure 3. Data Research Results on Professionalism Graduates

Based on the above data, it can be seen that on the professional indicator of PGSD student graduates have a good attitude on the mastery of factual 
knowledge about the SD-an relevant to the competence, graduates have the ability to think conceptually in solving problems in the work, graduates can use and adjust competence in the development of science, graduates have the ability to plan teaching and learning programs, graduates have the ability to carry out learning activities, graduates have the ability to lead / manage the learning process, graduates have the ability to assess the progress of teaching and learning, graduates have the ability to master the lesson, field of study or subjects held, graduates are able to organize both in learning and nonlearning, graduates perform guidance both in learning and non-learning, graduates are able to carry out evaluate ation both in learning and non-learning, and graduates using innovative media in learning appropriately. While the indicator that the result is good enough graduates master the concepts of subjects in elementary school that can be implemented in the field of occupation, graduates have the ability to think analysis in carrying out its work, graduates master the learning materials appropriately, and graduates use varied learning methods in learning appropriately.

Professional ability for a teacher is essential. based on the opinion of Sururi (2002: 2) professional ability of the teacher, covering 4 (four) aspects, that are: (a) ability of learning plan, (b) ability to implement and lead / manage teaching and learning process, (c) teaching, and (d) the ability to master the subject matter.

Based on the above data shows that $3 / 4$ indicators have reached the target. Indicators that still need to be improved are mastery of concepts, analytical skills, and appropriateness in the application of learning strategies.

\section{English proficiency}

Kemampuan Bahasa ingoris

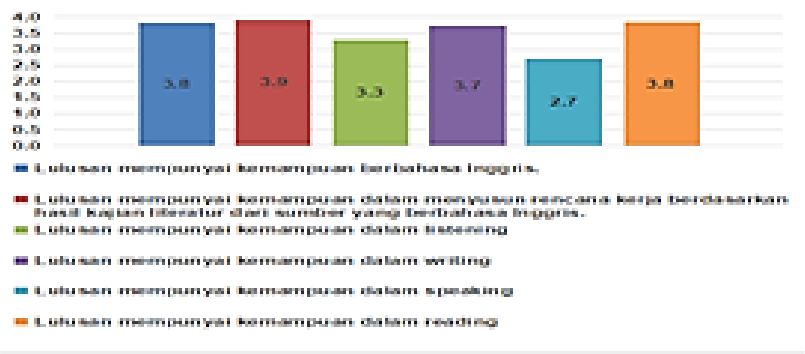

Figure 4. Data Research Results on English Proficiency

Based on the above data, it can be seen that the indicator of English proficiency of PGSD students has capability with good result in listening ability, writing skill, English proficiency, ability in compiling work plan based on literature review result from English speaking source, and ability in reading. While the ability with poor results is the ability to speak. The data shows that there needs to be an increase in English mastery.

\section{Use of Information Technology}

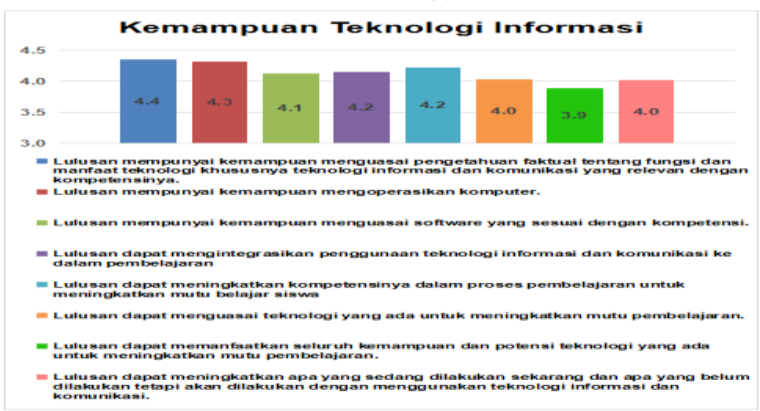

Figure 5. Data Research Results on Use of Information Technology

Based on the above data, it can be seen that the indicator of the use of information technology PGSD students have the ability with good results on the ability to master factual knowledge about the functions and benefits of technology, especially information and communication technology relevant to the competence, the ability to operate the computer, the ability to master the appropriate software

with competence, able to integrate the use of information and communication technology into learning, able to improve the competence in the learning process to improve the quality of student learning, able to master the existing technology to improve the quality of learning, and able to improve what is being done now and what has not been done but will be done using information and communication technology. While the ability with good results is that graduates can utilize all the capabilities and potential of existing technology to improve the quality of learning.

The data shows that the actual ability of students in the use of information technology students PGSD graduates have been good only students have not been able to apply the knowledge they already have in the process of learning that dilakaukan. This takes time to practice in the field.

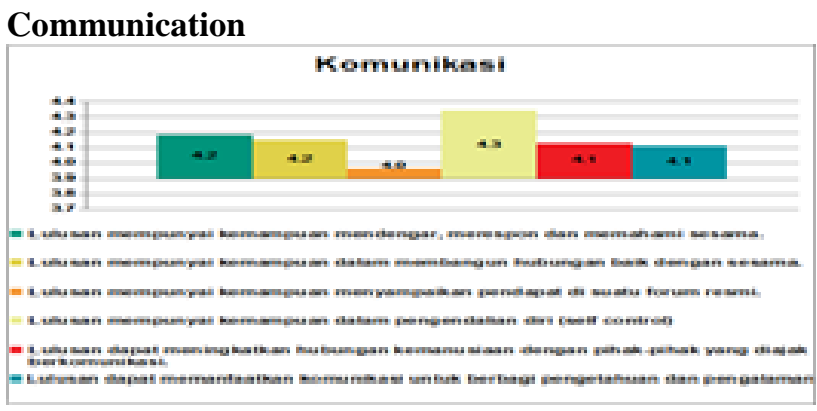

Based on the above data, it can be seen that on all indicators of communication skills of PGSD students generate good value. Indicators of communication skills are the ability to listen, respond 
and understand others, the ability in self-control (self control), the ability to improve humanitarian relationships with the parties invited to communicate, and the ability to use communication to share knowledge and experience, graduates have the ability to build good relations with others, and graduates have the ability to express opinions in an official forum. This data shows that PGSD graduate students already have good communication skills. The longer the students will be more trained to make good communication with all parties.

\section{Teamwork}

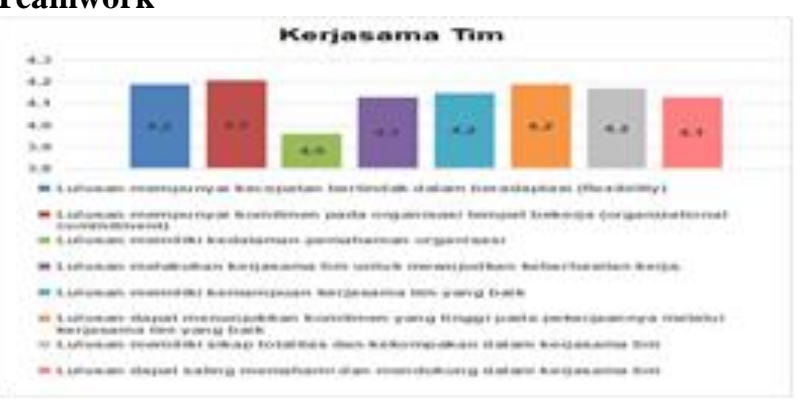

Figure 6. Data on Team Cooperation Research Results

Based on the above data, it can be seen that all indicators of teamwork of PGSD students have good results. Indicators of teamwork consist of graduates having flexibility in acting (flexibility), graduates have commitment to organizational commitment (organizational commitment), graduates doing teamwork to realize job success, graduates have good team cooperation skills, graduates can show high commitment on their work through good teamwork, graduates have an attitude of totality and cohesiveness in teamwork, graduates can understand and support each other in teamwork, and graduates have a deep understanding of the organization. In the opinion of Warsihna (2010: 9) stated that teamwork will unite the power of ideas that will lead to success. This team collaboration can be taught in the learning process in all courses. Students are accustomed to cooperate with their friends either he likes or does not like. Students should be taught to be tolerant with others, suppressing the selfishness that arises so that the learning objectives can be achieved well.

\section{Self-Development}

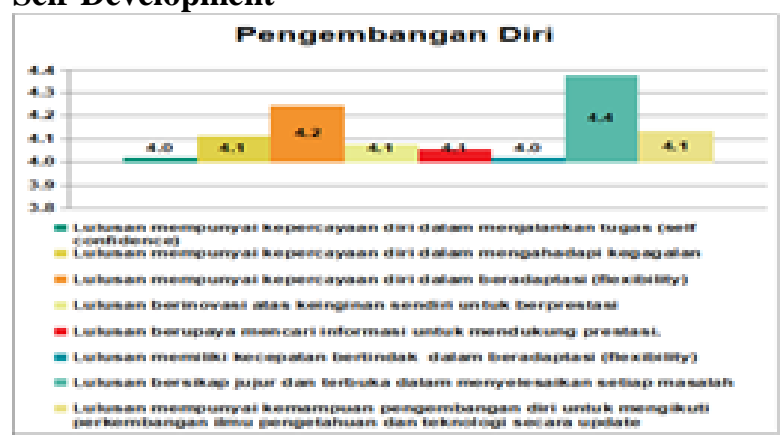

Based on the above data, it can be seen that all indicators of self-development, PGSD students have good results. Self-development can be done based on self-introspection and feedback from others. Feedback from others is done by requesting feedback in the form of information or judgment data about himself / herself from others (coworkers, superiors, subordinates, family members), covering everything about the attitudes and behaviors of a person who is seen, perceived by others who meet, or interact with it.

\section{Graduate User Satisfaction}

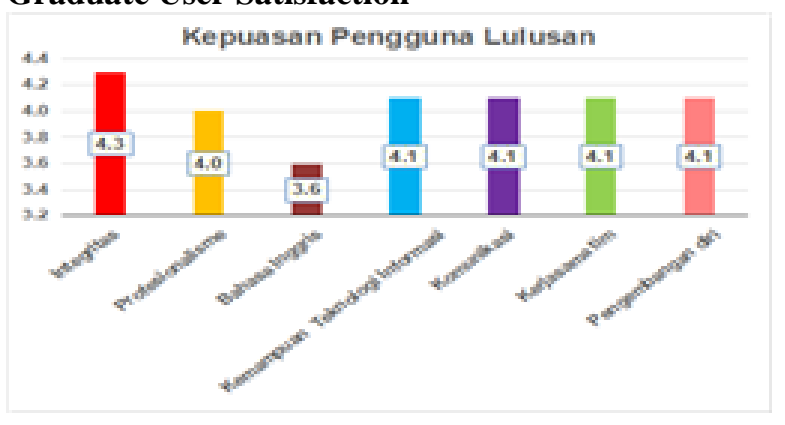

Figure 7. Results of Graduate User Satisfaction

Based on the results of the analysis obtained data that of the seven aspects of user satisfaction graduates researched results obtained that 6 (six) aspects produce good value, namely on aspects of integrity, professionalism, information technology skills, communication, teamwork and selfdevelopment. While aspects with good enough value obtained in English aspects.

\section{CONCLUSION}

User satisfaction of graduates can be measured from 7 (seven) aspects of the ability of PGSD graduate in the field. The seven aspects are integrity (ethics and morals), professionalism (expertise by field), English, information technology skills, communication, teamwork, and self-development. Based on data from research about user satisfaction PGSD student graduate obtained result that all indicator of integrity (100\%) yield good value. User satisfaction graduates produce good values in six aspects (85.7\%), namely aspects of integrity, professionalism, communication, use of information technology, teamwork, and selfdevelopment. While as much as one aspect (14.3\%) the results are quite good. This aspect is English proficiency. This indicates that the study program must be really serious in improving the English language ability of PGSD students to be able to learn it better. Good listening, writing, speaking, and grammar skills.

\section{REFERENCES}

Budimanta, Arif, Adi Prasetyo, dan Bambang Rudito. 2008. Corporate Social Responsibility: Alternatif 
bagi Pembangunan Indonesia. Jakarta: ICSD.

Indahwati, Darsono. Dharmmesta, Basu Swastha. 2008. Kontribusi involvement dan trust in a brand dalam membangun loyalitas pelanggan. Jurnal Ekonomi dan Bisnis Indonesia, Vol. 20, No. 3.

Moleong. J. Lexy. 2007. Metode Penelitian Kualitatif. Bandung: Rosdakarya.

Munawaroh. 2012. Pengaruh Motivasi dan Disiplin terhadap Kinerja Pegawai pada Dinas Kesehatan Kabupaten Banyuasin, Universitas Bina Darma, Kalimantan Timur.

Satori, Djam'an dan Komariah, Aan. 2009. Metodologi Penelitian Kualitatif. Bandung: Alfabeta.

Setyaningsih, Ira \& Abrori, Muchammad. 2013. Analisis Kualitas Lulusan Berdasarkan Tingkat Kepuasan Pengguna Lulusan. Jurnal Ilmiah Teknik Industri, Vol 12, No.1, Juni 2013.

Sugiyono. 2009. Metode Penelitian Kuantitatif Kualitatif Dan $R \& D$. Bandung: Alfabeta.

Sulastiyono, Agus. 2008. Manajemen Penyelenggaraan Hotel. Cetakan Keenam. Bandung: Penerbit Alfabeta.

Sururi, Aan. 2002. Meningkatkan Aktivitas Belajar Siswa Melalui Pendekatan Belajar Kooperatif Dengan Menggunakan Teknik Jigsaw. Skripsi (Tidak diterbitkan). Surakarta: UMS

Syaodih, Sukmadinata, Nana. 2009. Metode Penelitian Pendidikan. Bandung: Rosdakarya.

Tjiptono, Fandy. 2006. Manajemen Jasa. Edisi Pertama. Yogyakarta : Andi

Warsihna. Jaka. 2010. Modul Pelatihan Budaya Kerja Dan Kerja Sama Tim, KEMDIKBUD. Pusat Teknologi Informasi Dan Komunikasi Pendidikan: http://belajar.kemdikbud.go.id. 